\title{
Recent aspects of the regulation of intestinal mucus secretion
}

\author{
BY C. LABOISSE, A. JARRY, J. E. BRANKA, D. MERLIN, \\ C. BOU-HANNA AND G. VALLETTE \\ INSERM CJF 94-04, Faculté de Médecine, Nantes, France
}

\section{Données récentes concernant la régulation de la sécrétion de mucus par l'intestin}

\section{RÉSUMÉ}

L'épithélium spécialisé qui borde la muqueuse intestinale n'est pas seulement une barrière passive entre la lumière et le milieu intérieur; c'est un système complexe qui participe activement à la défense de la muqueuse. En particulier, les fonctions de transport $(\operatorname{IgA})$, de sécrétion vectorielle d'électrolytes $\left(\mathrm{Cl}^{-}\right)$et de macromolécules (mucines) constituent la première ligne de défense de cet épithélium. Ces fonctions de sécrétion sont régulées par des agents neuroendocrines et des médiateurs de l'inflammation et de l'immunité. Le développement de modèles 'in vitro' permettant d'étudier le mode d'action de ces médiateurs sur les fonctions sécrétoires intestinales est au coeur de la recherche en gastroentérologie. Les cultures dites organotypiques fondées sur le maintien in vitro de fragments de muqueuse intestinale et les préparations de cellules épithéliales isolées ont de sérieuses limitations notamment en termes de viabilité cellulaire. C'est pourquoi les recherches récentes se sont orientées vers le développement de lignées cellulaires différenciées et homogènes, issues de cancers coliques humains, qui maintiennent in vitro les fonctions différenciées qui sont celles des colonocytes in vivo. Nous présentons ici l'établissement et l'exploitation du modèle HT29-Cl.16E, issu de notre laboratoire, pour l'étude des récepteurs, de la signalisation intracellulaire et enfin des mécanismes distaux de l'exocytose des cellules à mucus de l'intestin.

The intestinal epithelial barrier consists of a continuous monolayer of polarized specialized cells lining the mucosal surface. In the small intestine, the epithelium lines the crypts and the villi. In the colon the epithelial cells line the crypts and the flat mucosal surface. The apical surface of this epithelium is routinely exposed to an enormous number of macromolecules of limitless variety that derive from many sources, including ingested food, resident bacteria and toxins.

It has become increasingly apparent that the single-cell-thick columnar epithelium cannot be thought of only as a physical barrier separating host tissues from potentiallytoxic macromolecules of various origins. In fact, the complex epithelial secretory functions that are tightly regulated by inputs from neurocrine, paracrine, endocrine and immune pathways, play a crucial role in maintaining the barrier function. These secretory functions intended to protect the mucosa may be conceptually categorized into two groups. Non-specific protection is provided by the apical secretion of mucins and $\mathrm{Cl}^{-}$. Specific protection is provided by transcytotic transport of immunoglobulin A. In addition, epithelial cell injury is associated with the basolateral secretion of cytokines 
exerting a chemo-attractant activity, thus leading to the recruitment of underlying inflammatory cells.

In the present review we focus primarily on recent advances in the regulation of mucus exocytosis from intestinal epithelial cells. Much of the progress in this field has derived from model systems utilizing cultured epithelial cells, primarily of intestinal (colonic) origin, and these in vitro studies will be at the core of the present review.

\section{IN VITRO MODELS FOR STUDYING THE REGULATION \\ OF MUCUS SECRETION}

Goblet cells are specialized secretory cells endowed with a variety of receptors coupled to intracellular signalling pathways that regulate the exocytotic machinery. Although considerable effort has been directed over the past years toward understanding the regulation of mucus secretion, very little is known about the chemical transmitters that regulate the secretion of mucus. In the same way their receptors on mucous cells and the intracellular transduction pathways are still poorly understood and are largely inferred from studies on other cell types.

There are several reasons for the failure to break new ground in this field of research. It is our inability to isolate a homogeneous preparation of goblet cells from the intestinal mucosa that is generally considered the key problem. To further complicate this situation, the specificity and sensitivity of many of the currently used methods for quantifying the secretion of mucus are often questionable. For example, assays based entirely on the incorporation of a radiolabelled glycoprotein precursor into acidprecipitable material in incubation media have been subject to various criticisms (Neutra $\&$ Forstner, 1987). In fact, non-mucin components are rapidly labelled by radioactive precursors such as ${ }^{35} \mathrm{SO}_{4}{ }^{2-}$, and ${ }^{3} \mathrm{H}$ - or ${ }^{14} \mathrm{C}$-labelled monosaccharides. In comparison, goblet-cell mucins are poorly labelled since the formation of new mucin granules is a slow process. Finally, as pointed out by Roomi et al. (1984), as well as Neutra \& Forstner (1987), the release of total radiolabelled glycoproteins is an unreliable index of mucin secretion. The lack of standardized methodology to quantify mucins often makes it difficult to compare the results obtained by various groups working on the regulation of mucin secretion.

\section{Organ-culture methods}

As a first in vitro approach to identify agents that could potentially alter the mucin secretory response from goblet cells, Neutra et al. (1984) have used rabbit mucosal biopsies in explant culture in combination with a morphological and autoradiographic assay. They found that acetylcholine and cholinomimetic drugs are potent goblet-cell secretagogues in normal intestinal tissue. The ultrastructural analysis of the goblet cells stimulated by acetylcholine showed that the rapid secretion of the stored granules was accomplished by sequential fusion of secretory granule membranes with the plasma membrane and with each other, a process referred to as 'compound exocytosis'.

However, the interpretation of the mechanisms involved in the secretory response of goblet cells to secretagogues was hampered by the cellular complexity and heterogeneity of the mucosal explants. To further complicate interpretation of organ-culture studies, some transmitters may be present in the mucosa, closely associated with the final target, the mucous cell. 


\section{Isolated intestinal cells}

The rationale for the use of isolated cells and epithelial sheets for studying the secretion of mucins is that certain fundamental problems, particularly the elucidation of the site of action of secretagogues, have been difficult to solve in studies based on organ-culture techniques.

Several methods have been devised for isolating either epithelial sheets or monodispersed populations of rat (Brasitus, 1982; Ahnen et al. 1988) or rabbit (Kaunitz, 1988) colonocytes. There is considerable similarity in the steps involved in these procedures. Ahnen et al. (1988) emphasized the importance of combining EDTA chelation and mechanical dissociation of everted colon segments. Functional activity of the dispersed cells as assessed by linear rates of incorporation of $\left[{ }^{3} \mathrm{H}\right]$ leucine and $\left[{ }^{3} \mathrm{H}\right]$ fucose was found to be maintained for $2 \cdot 5-3 \mathrm{~h}$ (Ahnen et al. 1988). However, colonic mucosa represents such a complex mixture of cell types that enrichment of various sub-populations becomes essential for certain studies. Although the isolation of populations of mature and immature rat colonocytes has been achieved by using a sequential dissociation technique (Ahnen et al. 1988), a method for separating highly-enriched populations of goblet cells is still needed.

\section{Cultured cells}

The ideal model for studying the secretion of mucins from goblet cells would be a monolayer culture of goblet cells that have retained in vitro the regulatory mechanisms operative in the same cells in vivo. Such a model would have several advantages: (1) the mucins would be produced in aseptic conditions, (2) they would be less contaminated than those produced in vivo or in organ culture, (3) a continuous monolayer culture would provide mucins with stable characteristics allowing reproducible experiments. Thus, much effort has been devoted in recent years to the culture of epithelial cells from the human colonic mucosa. Attempts at culturing disaggregated tissue have generally been unsuccessful.

Due to the difficulty of culturing normal intestinal cells, some human colonic cancer cell lines have attracted a great deal of research interest (Laboisse, 1989). As early as 1984 , we reported the isolation and the characterization of stably differentiated clones (Augeron \& Laboisse, 1984) from the human colonic adenocarcinoma cell line HT-29 (Fogh \& Trempe, 1975). The development of these clonal cell lines was made possible by the discovery in our laboratory that the treatment of HT-29 cells with sodium butyrate was able to cause the emergence of stably differentiated sub-populations from the undifferentiated parental cells in culture (Augeron \& Laboisse, 1984). This observation and the ability to grow these sub-populations as independent clonal cell lines have made possible the development of a goblet cell line $(\mathrm{Cl} .16 \mathrm{E})$ which is a very powerful model to study the regulation of mucus secretion.

$\mathrm{Cl} .16 \mathrm{E}$ cells can be maintained as homogeneous monolayers of goblet cells on microporous membranes in chambers. In this system the apical culture medium is separated from the basolateral culture medium. Using this culture system, it is possible to check the polarized distribution of receptors. It is also possible to evaluate the paracellular permeability of the monolayers by monitoring the electrical resistance. In addition, morphological studies are facilitated as filter-grown cells can be routinely processed exactly in the same way as biopsy samples. 
The exocytotic response of goblet cells in vitro can be measured by using a very sensitive and specific assay, referred to by us as the electrophoretic assay (Augeron et al. 1992). In this assay the secretory glycoproteins are metabolically labelled with $\left[{ }^{3} \mathrm{H}\right]$ glucosamine. Then ${ }^{3} \mathrm{H}$-labelled mucins are measured as ${ }^{3} \mathrm{H}$-labelled macromolecules trapped at the stacker-gel interface of $30 \mathrm{~g}$ polyacrylamide $/ \mathrm{kg}$ gels.

\section{REGULATION OF MUCIN EXOCYTOSIS: RECEPTORS \\ AND SIGNALLING SYSTEMS}

\section{Neuroendocrine agents}

In efforts to identify agents that could potentially interact with goblet-cell basolateral membranes to evoke a mucin exocytotic response, we have considered and tested neurotransmitters and peptides as candidate secretagogues. Acetylcholine, vasoactive intestinal peptide (VIP), neurotensin and its analogue neuromedin were agents that consistently stimulated an exocytotic response from $\mathrm{Cl} .16 \mathrm{E}$ goblet cells. Combined measurements of intracellular messengers ( $\left.\mathrm{Ca}^{2+}, \mathrm{cAMP}\right)$ and mucus exocytosis allowed us to study in detail the signalling pathways coupled to the activation of receptors in goblet cells (Bou-Hanna et al. 1994a). In addition, the manipulation of the $\mathrm{Ca}^{2+}$ content of the incubation medium showed that while the mucin secretory response to carbachol depends on both the release of $\mathrm{Ca}^{2+}$ from intracellular stores and a $\mathrm{Ca}^{2+}$ influx from external medium, the secretory response to neurotensin is based entirely on intracellular $\mathrm{Ca}^{2+}$ mobilization. Finally, evaluation of the cross-talk between the cAMP pathway stimulated by VIP and the $\mathrm{Ca}^{2+}$ pathway stimulated by neurotensin or carbachol led to the conclusion that the potentiated secretory response elicited by the combined action of carbachol and VIP requires extracellular $\mathrm{Ca}^{2+}$.

\section{Inflammatory and immune agents}

Inflammatory conditions lead to the local production of high amounts of inflammatory and immune mediators (cytokines). Among these, extracellular ATP and interleukin-1 (IL-1) have been shown to function as goblet-cell secretagogues.

ATP is a ubiquitous intracellular constituent so that every cell is a potential source for this nucleotide. It can be released during neurotransmission or from 'dense granules' during blood platelet activation. Interestingly, inflammatory conditions can lead to the local production of high amounts of extracellular ATP which is released from vascular endothelial cells as well as cytotoxic and helper T lymphocytes. Extracellular ATP elicits mucus secretion from the respiratory mucosa. In collaboration with Dr Hopfer (Department of Biophysics, CWRU, Cleveland, Ohio, USA), we tested the effects of extracellular ATP and ATP analogues on Cl.16E goblet cells grown in chamber cultures. When applied to the apical medium, ATP elicited a strong and rapid exocytotic response. This response was mediated by the activation of $P_{2}$ receptors located at the apical surface of the goblet cells (Merlin et al. 1994). In vivo, the source of lumen ATP is unclear at the moment, but it could be inflammatory cells that migrate into the intestinal lumen or a spillover from the tissue because of leaky tight junctions. In situ, the consequences of stimulation of the $\mathrm{P}_{2}$ receptors would be massive secretion of both fluid and mucin from the epithelial surface. These secretions should have a major cleansing 
effect by removing noxious agents, including bacteria, from the surface and, therefore, may be part of the defence mechanisms of epithelia.

IL-1 is a pro-inflammatory cytokine present in the gastrointestinal mucosa, where it is released by immune cells activated by lamina propria during inflammation. IL-1 was recently found to induce mucin release from explant cultures of mouse duodenum (Cohan et al. 1991). The recent identification of specific receptors for IL-1 on several human colonic cell lines, including Cl.16E (Jarry et al. 1994b), provided the rationale for testing the effect of this cytokine on mucus secretion. Our results showed that IL-1 can directly stimulate mucin exocytosis from a cultured goblet cell line.

NO is a potent inter- and intracellular mediator which is produced by several cell types in the intestinal wall, including endothelial and epithelial cells. In addition, a dramatic increase in NO production is observed in inflammatory states. Recent investigations based on the utilization of NO donors have shown that this agent is able to stimulate the secretion of mucus from rat gastric mucosal cells (Brown et al. 1993). The explanation for these findings is that NO stimulates mucus exocytosis via cGMP accumulation in mucus cells. This emerging picture of NO action on the biology of epithelial cells is likely to become more complex in the future, as NO can affect a variety of targets inside the cells depending on the redox state. In addition, this molecule is able to combine with superoxide ions yielding peroxynitrite which can lead to oxidative injury (Stamler et al. 1992). In this context, further studies are needed to decipher the full range of actions of this agent on epithelial cells.

\section{Toxins}

The apical surface of the intestinal epithelium is a target for several toxins. The demonstration that toxins can directly alter the secretory function of colonocytes is typified by the action of cholera toxin on $\mathrm{Cl}^{-}$secretory cells. We recently showed by using the $\mathrm{Cl} .16 \mathrm{E}$ model that cholera toxin, in addition to stimulating the $\mathrm{Cl}^{-}$secretory function of epithelial cells, is able to elicit a sustained mucin exocytotic response associated with an increase in mucin biosynthesis and MUC-2 gene expression (Jarry et al. 1994a).

Recent investigations have focused on two toxins (toxin A and toxin B) produced by Clostridium difficile that have deleterious effects on the colonic mucosa via direct and indirect effects on the epithelium. Several recent studies tend to show that these toxins may be instrumental in unravelling the mechanisms underlying the barrier function of the intestinal epithelium. Studies based on colonic mucosa maintained in Ussing chambers and on colonic cell lines have shown that toxin A increases junctional permeability of intestinal monolayers in vitro and inhibits the exocytotic response to secretagogues (Bou-Hanna et al. 1994b). These effects of toxin A on the barrier function may be due to its action on the microfilament system.

\section{CONCLUSION}

A great advance has recently been made in our understanding of the biology of mucus-secreting cells through the exploitation of differentiated cell lines. These cultured cells, however, are transformed permanent cell lines. The challenge for the future will be to identify and characterize the receptors and signalling systems regulating the mucus exocytotic response on primary normal intestinal epithelial cells. 


\section{REFERENCES}

Ahnen, D. J., Reed, T. A. \& Bozdech, J. M. (1988). Isolation and characterization of populations of mature and immature rat colonocytes. American Journal of Physiology 254, G610-G621.

Augeron, C. \& Laboisse, C. L. (1984). Emergence of permanently differentiated cell clones in a human colonic cancer cell line in culture after treatment with sodium butyrate. Cancer Research 44, 3961-3969.

Augeron, C., Voisin, T., Maoret, J. J., Berthon, B., Laburthe, M. \& Laboisse, C. L. (1992). Neurotensin and neuromedin $\mathrm{N}$ stimulate mucin output from human goblet cells $(\mathrm{Cl} .16 \mathrm{E})$ via neurotensin receptors. American Journal of Physiology 262, G470-G476.

Bou-Hanna, C., Berthon, B., Combettes, L., Claret, M. \& Laboisse, C. L. (1994a). Role of calcium in carbachol- and neurotensin-induced mucin exocytosis in a human colonic goblet cell line and cross-talk with cAMP pathway. Biochemical Journal 299, 579-585.

Bou-Hanna, C., Jarry, A., Nguyen Van, P. \& Laboisse, C. L. (1994b). Clostridium difficile toxin-A polarized entry and modulation of exocytosis in a human colonic mucus-secreting cell line (Cl.16E). Gastroenterology 106, A655.

Brasitus, T. A. (1982). Isolation of proliferative epithelial cells from the rat cecum and proximal colon. Analytical Biochemistry 123, 364.

Brown, J. F., Keates, A. C., Hanson, P. J. \& Whittle, J. R. (1993). Nitric oxide generators and cGMP stimulate mucus secretion by rat gastric mucosal cells. American Journal of Physiology 265, G418-G422.

Cohan, V. L., Scott, A. L., Dinarello, C. A. \& Prendergast, R. A. (1991). Interleukin-1 is a mucus secretagogue. Cellular Immunology 136, 425-434.

Fogh, J. \& Trempe, G. (1975). New human tumor cell lines. In Human Tumor Cells in vitro, pp. 115-141 [J. Fogh, editor]. New York: Plenum Press.

Jarry, A., Merlin, D., Velcich, A., Hopfer, U., Augenlicht, L. H. \& Laboisse, C. (1994a). Interferon- $\gamma$ modulates cAMP-induced mucin exocytosis without affecting mucin gene expression in a human colonic goblet cell line. European Journal of Pharmacology (Molecular Pharmacology) 267, 95-103.

Jarry, A., Vallette, G. \& Laboisse, C. L. (1994b). Stimulation of mucin secretion by a direct action of interleukin-1 $1 \beta$ on colonic epithelial cells. Gastroenterology 106, A706.

Kaunitz, J. D. (1988). Preparation and characterization of viable epithelial cells from rabbit distal colon. American Journal of Physiology 254, G502-G512.

Laboisse, C. L. (1989). Differentiation of colon cells in culture. In Cell and Molecular Biology of Colon Cancer, pp. $27-43$ [L. H. Augenlicht, editor]. Boca Raton: CRC Press.

Merlin, D., Augeron, C., Tien, X.-Y., Guo, X., Laboisse, C. L. \& Hopfer, U. (1994). ATP-stimulated electrolyte and mucin secretion in the human intestinal goblet cell line HT29-Cl.16E. Journal of Membrane Biology 137, 137-149.

Neutra, M. R. \& Forstner, J. F. (1987). Gastrointestinal mucus: synthesis, secretion and function. In Physiology of the Gastrointestinal Tract, pp. 975-1009 [L. R. Johnson, J. Christensen, M. J. Jackson, E. D. Jacobson and J. H. Walsh, editors]. New York: Raven Press.

Neutra, M. R., Philipps, T. L. \& Philipps, T. E. (1984). Regulation of intestinal goblet cells in situ, in mucosal explants and in the isolated epithelium. In Mucus and Mucosa, pp. $20-39$ [J. Nugent and M. O'Connor, editors]. London: Pitman Publishing Ltd.

Roomi, N., Laburthe, M., Fleming, N., Crowther, R. \& Forstner, J. (1984). Cholera-induced mucin secretion of rat intestine: lack of effect of cAMP, cycloheximide, VIP, and colchicine. American Journal of Physiology 247, G140-G148.

Stamler, J. S., Singel, D. J. \& Loscalzo, J. (1992). Biochemistry of nitric oxide and its redox-activated forms. Science 258, 1898-1902. 